\title{
Salt tolerance of the harmful cyanobacterium Microcystis aeruginosa
}

\author{
Linda Tonk, Kim Bosch, Petra M. Visser, Jef Huisman* \\ Aquatic Microbiology, Institute for Biodiversity and Ecosystem Dynamics, University of Amsterdam, Nieuwe Achtergracht 127, \\ 1018 WS Amsterdam, The Netherlands
}

\begin{abstract}
Increasing salinities in freshwater ecosystems caused by agricultural practices, droughts, or rise in sea level are likely to affect the species composition of phototrophic microorganisms. Cosmopolitan freshwater cyanobacteria of the Microcystis genus can produce the toxin microcystin, and present a potential health risk in many eutrophic lakes. In this study, M. aeruginosa Strain PCC 7806 was grown in semi-continuous turbidostats to investigate the effect of increasing salinity on growth rate, microcystin cell quota, microcystin production and extracellular microcystin concentration. Specific growth rate, microcystin cell quota and microcystin production remained more or less unaffected by salinity levels up to $10 \mathrm{~g} \mathrm{l}^{-1}$. Specific growth rate collapsed when salinity was increased beyond $10 \mathrm{~g} \mathrm{l}^{-1}$ for several weeks. Cell size and microcystin cell quota decreased while extracellular microcystin concentrations increased at salinities above $10 \mathrm{~g} \mathrm{l}^{-1}$, indicating leakage and/or cell lysis. Salt-shock experiments revealed that $M$. aeruginosa can temporarily endure salinities as high as $17.5 \mathrm{~g} \mathrm{l}^{-1}$. These results indicate that, for a freshwater species, $M$. aeruginosa has a high salt tolerance. Rising salinities in freshwater ecosystems are therefore unlikely to suppress $M$. aeruginosa blooms, and may in fact enhance the exposure of aquatic organisms to elevated concentrations of extracellular microcystins.
\end{abstract}

KEY WORDS: Harmful algal blooms · Harmful cyanobacteria $\cdot$ Microcystis $\cdot$ Microcystins $\cdot$ Salinity HPLC

\section{INTRODUCTION}

Freshwater ecosystems are confronted with increasing salinity on a world-wide scale, due to a variety of different processes, including long-term droughts, rising seawater levels, agricultural practices, or specific water management strategies (Williams 2001, Nielsen et al. 2003). Rising salt concentrations are known to affect numerous freshwater biota (Hart et al. 1991, 2003, James et al. 2003), and may shift the species composition of phytoplankton communities (Ahmed et al. 1985, Wilson et al. 1994, Mohapatra et al. 1998, Muylaert et al. 2000, Moisander et al. 2002, Bordalo \& Vieira 2005).

Cyanobacteria are found across a wide range of different salinities, including hypersaline waters (DasSarma \& Arora 2001, available at http://els.wiley.com). Most freshwater cyanobacteria, however, do not sur- vive in brackish or seawater. Microcystis aeruginosa is a harmful cyanobacterium that occurs worldwide in freshwater lakes. The toxins produced by $M$. aeruginosa are commonly known as microcystins, and belong to an extensive group of cyclic heptapeptides comprising at least 71 described variants (Codd et al. 2005). Microcystins can cause liver damage through inhibition of protein phosphatases (MacKintosh et al. 1990). Usually, microcystins are concentrated inside Microcystis spp. cells, whereas extracellular microcystin concentrations remain low. The occurrence of Microcystis spp. is related to environmental factors such as excess nutrient availability, high temperature and a stable water column with little vertical mixing (Reynolds \& Walsby 1975, Huisman et al. 2004, Visser et al. 2005). During calm summer weather, Microcystis spp. float towards the surface and form dense scums, thereby causing serious health risks (Chorus 
\& Bartram 1999, Carmichael et al. 2001, Huisman et al. 2005).

In The Netherlands, characterized by large stretches of land reclaimed from sea (called 'polders'), Microcystis spp. blooms are a widespread nuisance. Because of increasing demands for freshwater irrigation and slowly intruding seawater, many of the eutrophic lakes in these polder areas face elevated salinities during summer. Furthermore, the possibility is being considered to convert freshwater lakes into brackish waters to reduce Microcystis spp. growth and to restore former estuarine ecosystems (Verspagen et al. 2006). As a result, the salinity in many Microcystis spp.-dominated lakes in The Netherlands is slowly increasing. However, little is known about the effect of elevated salinity on the growth rate and microcystin production of this genus.

Preliminary studies in batch cultures suggest that the growth rate of Microcystis aeruginosa might be stimulated by rising salinities, at least up to a salinity of $\sim 2 \mathrm{~g} \mathrm{l}^{-1}$ (recalculated data of Prinsloo \& Pieterse 1994). Furthermore, $M$. aeruginosa seems to have a relatively high salt tolerance, estimated at $7 \mathrm{~g} \mathrm{l}^{-1}$ by Otsuka et al. (1999), $10 \mathrm{~g} \mathrm{l}^{-1}$ by Orr et al. (2004) and $14 \mathrm{~g} \mathrm{l}^{-1}$ by Verspagen et al. (2006). If these observations are correct, $M$. aeruginosa blooms might actually be favored in slightly brackish waters.

In this study, the strain Microcystis aeruginosa PCC 7806 was grown in controlled semi-continuous turbidostats to investigate in detail how elevated salt concentrations affect its growth rate and intracellular and extracellular microcystin content. We used 2 approaches: in one set of experiments, cells were exposed to slowly rising levels of salinity, providing sufficient time for cells to adjust their physiology to the prevailing osmotic conditions; in the other set of experiments, $M$. aeruginosa cells were exposed to a sudden salt shock to examine whether cells would respond differently when confronted with a rapid rise in salinity.

\section{MATERIALS AND METHODS}

Organism and culture conditions. Microcystis aeruginosa Strain PCC 7806 was provided by the Pasteur Institute, Paris. The strain was originally isolated from the Braakman Reservoir, The Netherlands, in 1972. We cultured this strain as single cells in semi-continuous cultures, using a turbidostat approach (Huisman et al. 2002). The optical density $(750 \mathrm{~nm})$ of the turbidostats was kept constant between 0.1 and $0.2 \mathrm{~cm}^{-1}$ by diluting the culture with nutrient-rich mineral medium once every $2 \mathrm{~d}$. Flat culture vessels with a working volume of $400 \mathrm{ml}$ were used in combination with a constant aeration of filtered and moistened air to ensure homogeneous mixing and to provide sufficient amounts of inorganic carbon. A cooling vessel of the same dimensions as the culture vessel was placed between the culture vessel and the light source to maintain a constant temperature of $23 \pm 1^{\circ} \mathrm{C}$. Light was provided by white fluorescent tubes (Philips PL-L 24W/840/4P), directed towards the front surface of the culture vessel. Incident irradiance $\left(I_{\text {in }}\right)$ and outgoing irradiance $\left(I_{\text {out }}\right)$ were measured with a LI-COR LI-250 quantum photometer at 7 points on the front surface and 7 points on the back surface of the culture vessel, respectively. The average photon irradiance inside the culture vessel was calculated as $I_{\text {avg }}=\left(I_{\text {in }}-I_{\text {out }}\right) /\left(\ln I_{\text {in }}-\ln I_{\text {out }}\right)$ (Huisman et al. 2002). Cultures were run in triplicate on a 12:12 h light:dark cycle, with a depth-averaged photon irradiance of $I_{\text {avg }}=110 \pm 20 \mu \mathrm{mol}$ photons $\mathrm{m}^{-2}$ $\mathrm{s}^{-1}$ during the light period.

Experimental outline. Our mineral medium was based on the $\mathrm{O} 2$ medium, which contains the macronutrients $\mathrm{MgSO}_{4} \cdot 7 \mathrm{H}_{2} \mathrm{O}\left(50 \mathrm{mg} \mathrm{l}^{-1}\right), \mathrm{NaNO}_{3}\left(500 \mathrm{mg} \mathrm{l}^{-1}\right), \mathrm{K}_{2} \mathrm{HPO}_{4}$ $\left(25 \mathrm{mg} \mathrm{l}^{-1}\right), \mathrm{CaCl}_{2} \cdot 2 \mathrm{H}_{2} \mathrm{O}\left(13 \mathrm{mg} \mathrm{l}^{-1}\right), \mathrm{NaHCO}_{3}(20 \mathrm{mg}$ $\left.\mathrm{l}^{-1}\right)$ as well as a $\mathrm{FeCl}_{2} \cdot 4 \mathrm{H}_{2} \mathrm{O}\left(2.2 \mathrm{mg} \mathrm{l}^{-1}\right)$ and a variety of trace metals (van Liere \& Mur 1978). O2 medium has a total salinity of $0.6 \mathrm{~g} \mathrm{l}^{-1}$. In order to detect the effect of slowly rising salinity, $\mathrm{NaCl}$ was added to this mineral medium to increase the salinity in a stepwise fashion to the following levels: from 0.6 (O2 medium) to 0.7 , $0.85,1.1,1.35,1.6,2.5,3.6,4.6,5,7.5,10,12.5,15$ and $17.5 \mathrm{~g} \mathrm{l}^{-1}$ (seawater has a salinity of $\sim 35 \mathrm{~g} \mathrm{l}^{-1}$ ). Cultures were grown in triplicate at a constant salinity level for a period of $2 \mathrm{wk}, 1 \mathrm{wk}$ for acclimation and $1 \mathrm{wk}$ for sampling. After each $2 \mathrm{wk}$ period the salinity of the cultures was increased to the next level by adding the required amount of salt during a dilution event. Additionally, 3 salt-shock experiments were performed in which Microcystis aeruginosa cells, pregrown in $\mathrm{O} 2$ medium, were directly exposed to salinities of 10,15 and $17.5 \mathrm{~g} \mathrm{l}^{-1}$, without the opportunity of gradually adjusting to intermediate salinities. The salt-shock experiments were again carried out in semi-continuous turbidostats, and the required amount of salt was added during a dilution event. The salt-shock experiments were run in triplicate using the same conditions as described above.

Sampling and microcystin analysis. The experiments with gradually increasing salinities were sampled 4 times during each 2 wk period, on Days 8, 10, 12 and 14 after the imposed salinity increase. The salt-shock experiments were monitored for a period of $10 \mathrm{~d}$ and sampled every other day. Samples were all taken on the same time of day to reduce possible variation in the data due to the light-dark cycle. Aliquots of all samples were analyzed in triplicate for cell concentration and intra- and extracellular microcystin concentration. 
Intracellular microcystin concentrations were expressed per cell (cell quota). Cell concentrations and cell size were measured with a cell counter (Casy 1 TTC, Schärfe System). Since the semi-continuous turbidostats were diluted once every $2 \mathrm{~d}$, the specific growth rate $(\mu)$ can be calculated as:

$$
\mu=\frac{\ln x_{2}-\ln x_{1}}{t_{2}-t_{1}}
$$

where $t_{1}$ is the time directly after a dilution event, $t_{2}$ the time directly before the next dilution event (2 d later), and $x_{1}$ and $x_{2}$ are the cell concentrations at Times $t_{1}$ and $t_{2}$, respectively. Note that Eq. (1) calculates net $\mu$, because the cultures were exposed to diel fluctuations in the form of a light-dark cycle. Microcystin production was calculated according to Long et al. (2001) as the product of microcystin cell quota and $\mu$.

For intracellular microcystin analysis, $10 \mathrm{ml}$ of the culture suspension was filtered in triplicate using Whatman GF/C filters (pore size $\sim 1.2 \mu \mathrm{m}$ ). Filters were freeze dried and stored at $-20^{\circ} \mathrm{C}$. Microcystin was extracted in $75 \%$ methanol (3 extraction rounds) as described by Fastner et al. (1998) with an extra step for grinding the filters in a Mini Beadbeater (Biospec Products) with $0.5 \mathrm{~mm}$ silica beads (Tonk et al. 2005). Dried extracts were stored at $-20^{\circ} \mathrm{C}$ and dissolved in $50 \% \mathrm{MeOH}$ for analysis of microcystin content using high performance liquid chromatography (HPLC) with photodiode array detection (Kontron Instruments). The extracts were separated using a 30 to $70 \%$ acetonitrile gradient with $0.05 \%$ trifluoroacetic acid at a flow of $1 \mathrm{ml} \mathrm{min}^{-1}$ and a LiChrospher 100 ODS $5 \mu \mathrm{m}$ LiChorCART 250-4 cartridge system (Merck). The different microcystin variants were identified based on their characteristic UV-spectra and quantified by means of an MC-LR gravimetrical standard kindly provided by the Laboratory of Microbiology of the University of Dundee.

For extracellular microcystin analysis, the effluent from the filtered culture suspension used for intracellular microcystin analysis was freeze dried and resuspended in $1.5 \mathrm{ml}$ Milli-Q. We expected that extracellular microcystin concentrations would be below the detection limit of the HPLC. Therefore, extracellular microcystin concentrations were determined using an enzyme-linked immunosorbent assay (ELISA), according to the protocol of the 'Microcystin plate kit' (EnviroLogix).

Data analysis. We used ANOVA to test for significant differences between the 3 salt-shock experiments $\left(10,15\right.$ and $\left.17.5 \mathrm{~g} \mathrm{l}^{-1}\right)$ in combination with Tukey's (HSD) post-hoc test to compare the means. Homogeneity of the variances was checked by Levene's test. The statistical tests were carried out in SPSS Version 11.

\section{RESULTS}

\section{Gradually increasing salinity}

Growth rates. The specific growth rate $(\mu)$ of Microcystis aeruginosa Strain PCC 7806 remained constant at around $0.40 \mathrm{~d}^{-1}(\mathrm{SD}=0.05 ; \mathrm{N}=12)$ up to a salinity of $10 \mathrm{~g} \mathrm{l}^{-1}$ (Fig. 1A). This was followed by an abrupt collapse to zero growth at 12.5 and $15 \mathrm{~g} \mathrm{l}^{-1}$.

Cell size. Mean cell size was $34 \mu^{3}(\mathrm{SD}=1.6 ; \mathrm{N}=5)$ in the salinity range of 0.6 to $10 \mathrm{~g} \mathrm{l}^{-1}$. At higher salinity, cell size decreased (Fig. 1B). The smallest cell size was approximately $20 \mathrm{\mu m}^{3}$ at a salinity of $15 \mathrm{~g} \mathrm{l}^{-1}$ (Fig. 1B).

Intracellular microcystin. Microcystis aeruginosa Strain PCC 7806 produced microcystin (MC) variants MC-LR and $\left[\mathrm{Asp}^{3}\right] \mathrm{MC}-\mathrm{LR}$. The peaks of $\left[\mathrm{Asp}^{3}\right] \mathrm{MC}-\mathrm{LR}$ and MC-LR could not be separated completely by means of HPLC. Therefore both peaks were merged and are referred to as total microcystin. Total microcystin cell quota was on average $45 \mathrm{fg} \mathrm{cell}^{-1}(\mathrm{SD}=6.7$; $\mathrm{N}=10$ ) for salinity levels up to $8 \mathrm{~g} \mathrm{l}^{-1}$. Above $8 \mathrm{~g} \mathrm{l}^{-1}$ the total microcystin content decreased (Fig. 1C). Total microcystin production was on average $18 \mathrm{fg} \mathrm{cell}^{-1} \mathrm{~d}^{-1}$ $(\mathrm{SD}=3.8 ; \mathrm{N}=11)$ in the salinity range from 0.6 to $10 \mathrm{~g} \mathrm{l}^{-1}$, and zero at higher salinities (Fig. 1D).

Extracellular microcystin. The extracellular microcystin concentration was not affected by salinity levels up to $10 \mathrm{~g} \mathrm{l}^{-1}$, where it amounted to approximately $16 \%$ of the total (intra- and extracellular) microcystin concentration in the culture vessels ( $\mathrm{SD}=1.6 ; \mathrm{N}=5)$. At $15 \mathrm{~g} \mathrm{l}^{-1}$, the extracellular microcystin concentration increased to almost $100 \%$ of the total microcystin concentration (Fig. 1E).

\section{Salt-shock experiments}

Growth rates. Microcystis aeruginosa $\mu$ was reduced upon exposure to a sudden increase in salinity in the salt-shock experiments (Fig. 2A). $\mu$ recovered within a week in the salt-shock experiment with $10 \mathrm{~g} \mathrm{l}^{-1}$. The $M$. aeruginosa population was clearly negatively affected by the salt-shock experiments at higher salinities, but was nevertheless still able to grow for $9 \mathrm{~d}$ when suddenly exposed to salinities as high as $17.5 \mathrm{~g}$ $\mathrm{l}^{-1}$. At Day 9, the growth rates at salinities 10, 15 and $17.5 \mathrm{~g} \mathrm{l}^{-1}$ differed statistically significantly from each other, decreasing at higher salinities (Fig. 2A; ANOVA: $\left.F_{2,6}=121, \mathrm{p}<0.001\right)$.

Cell size. Mean cell size was $35 \mu^{3}(\mathrm{SD}=0.2 ; \mathrm{N}=$ 54) throughout the salt-shock experiment, with a slight increase towards the end of the experiment (Fig. 2B). At Day 9, the cell size of cells grown at a salinity of $17.5 \mathrm{~g} \mathrm{l}^{-1}$ was statistically significantly larger than those cultured at 10 and $15 \mathrm{~g} \mathrm{l}^{-1}$; cell sizes at 10 and 


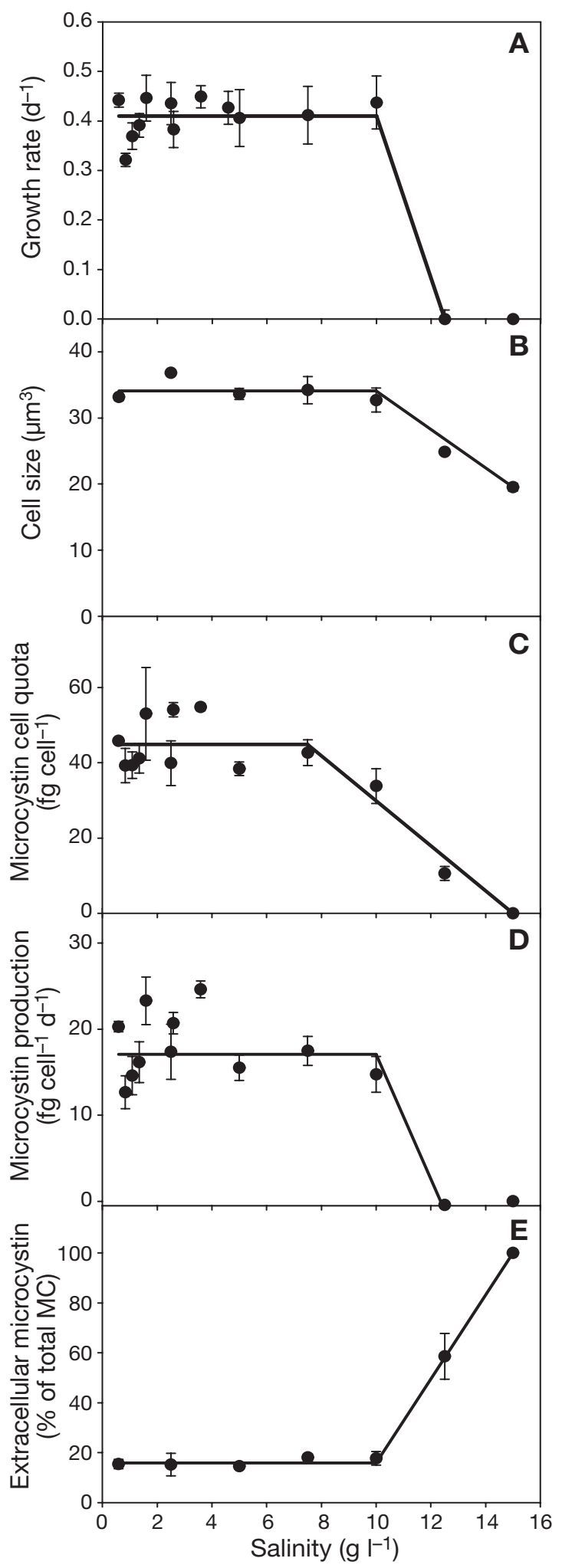

Fig. 1. Microcystis aeruginosa. Mean $\pm \mathrm{SD}(\mathrm{N}=3)$ effects of salinity on (A) specific growth rate, (B) average cell size, (C) total microcystin cell quota, (D) microcystin production, and (E) extracellular microcystin concentration as a percentage of total (intra- and extracellular) microcystin concentration. Curves represent means at low salinities, and indicate steep changes at high salinities

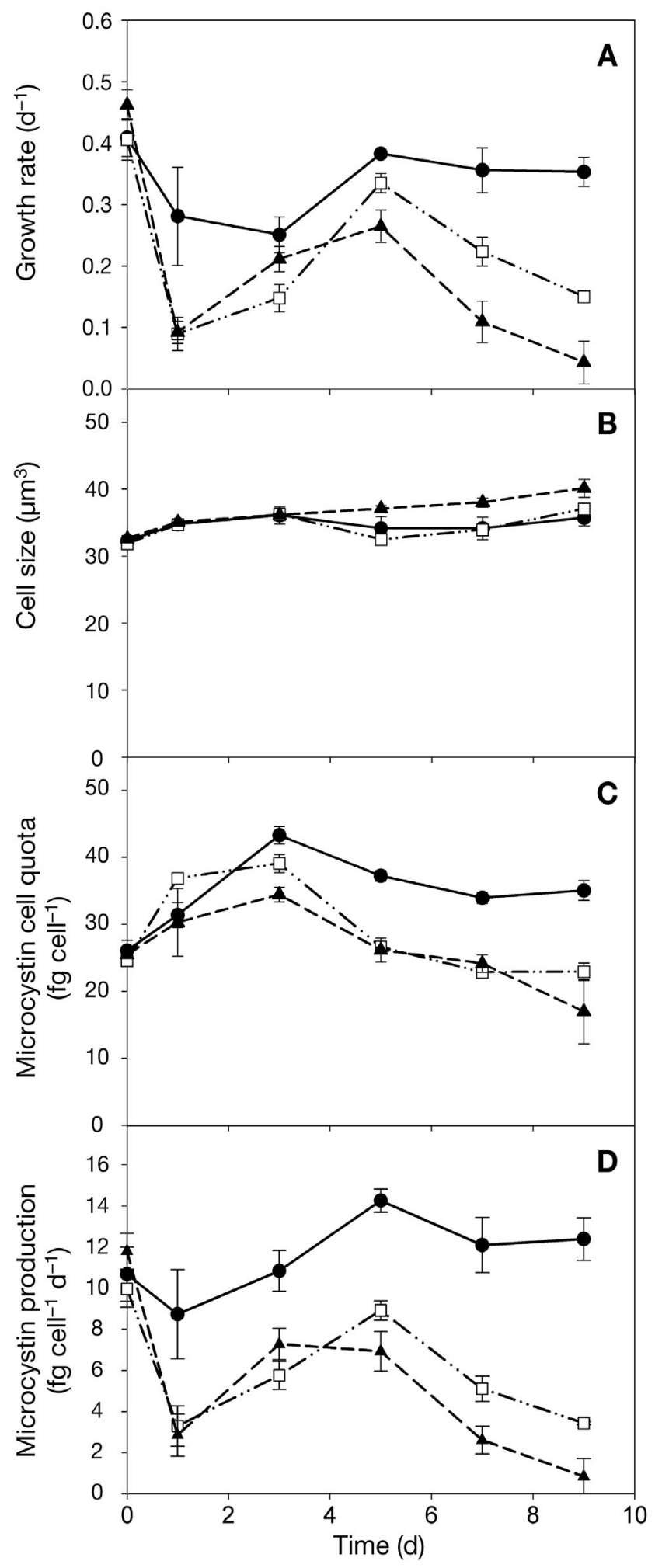

Fig. 2. Microcystis aeruginosa. Mean $\pm \mathrm{SD}(\mathrm{N}=3)$ time course of (A) specific growth rate, (B) cell size, (C) total microcystin cell quota and (D) microcystin production during salt-shock

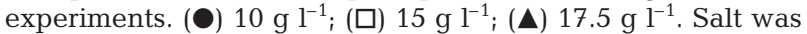
added at Day 0 , directly after first sampling point 
$15 \mathrm{~g} \mathrm{l}^{-1}$ were not statistically significantly different (Fig. 2B; ANOVA: $F_{2,6}=11.6, \mathrm{p}<0.01$ ).

Intracellular microcystin. The microcystin cell quota of cells exposed to salinities of 10,15 and $17.5 \mathrm{~g} \mathrm{l}^{-1}$ initially increased (Fig. 2C). After $3 d$, the microcystin contents of cells exposed to $10 \mathrm{~g} \mathrm{l}^{-1}$ remained high, while the microcystin contents at 15 and $17.5 \mathrm{~g} \mathrm{l}^{-1}$ decreased. At Day 9, microcystin cell quota was significantly higher at a salinity of $10 \mathrm{~g} \mathrm{l}^{-1}$ than at salinities of 15 and $17.5 \mathrm{~g} \mathrm{l}^{-1}$ (Fig. $2 \mathrm{C}_{\text {; }}$ ANOVA: $F_{2,6}=28$, $\mathrm{p}<$ 0.01).

Microcystin production of cells exposed to a salt shock of $10 \mathrm{~g} \mathrm{l}^{-1}$ decreased during the first day, but recovered fully during the following days (Fig. 2D). Total microcystin production of cells exposed to salt shocks of 15 and $17.5 \mathrm{~g} \mathrm{l}^{-1}$ also decreased during the first day, then increased during the next few days, after which the microcystin production collapsed. At Day 9, microcystin production at salinities of 10, 15 and $17.5 \mathrm{~g} \mathrm{l}^{-1}$ were significantly different from each other with a statistically significant decrease at higher salinities (Fig. 2D; ANOVA: $F_{2,6}=121$, $p<0.001$ ).

Extracellular microcystin. Extracellular microcystin concentrations measured at Day 7 were 17, 15 and $30 \%$ of the total microcystin concentration (intra- and extracellular) in the cultures exposed to salinities of 10 , 15 and $17.5 \mathrm{~g} \mathrm{l}^{-1}$, respectively.

\section{DISCUSSION}

The growth rate, microcystin cell quota, and microcystin production of the harmful cyanobacterium Microcystis aeruginosa Strain PCC 7806 remained unaffected up to a salinity of $10 \mathrm{~g} \mathrm{l}^{-1}$ (Fig. 1). These results from controlled semi-continuous turbidostats confirm earlier findings in batch cultures (Otsuka et al. 1999, Orr et al. 2004, Verspagen et al. 2006) that, for a freshwater species, Microcystis has a high salt tolerance. We investigated only a single $M$. aeruginosa strain. Therefore, it is not clear to what extent our findings can be extrapolated to other $M$. aeruginosa strains. However, Otsuka et al. (1999) reported a rather similar salt tolerance of 4 different $M$. aeruginosa strains. Moreover, the observed salt tolerance is consistent with observations of Microcystis spp. blooms in brackish waters, e.g. in the Patos Lagoon Estuary in Brazil (Matthiensen et al. 2000), the Oued Mellah reservoir, Morocco (Sabour et al. 2002), the Swan River Estuary, Australia (Robson \& Hamilton 2003), San Francisco Bay, USA (Lehman et al. 2005), and the Kucukcekmece Lagoon, Turkey (Albay et al. 2005). The growth rate was not stimulated by salinity in our experiments. Hence, our results do not support preliminary observations of Prinsloo \& Pieterse (1994) that the growth rate of Microcystis spp. might actually benefit from a slightly brackish environment. Cell size was reduced above $10 \mathrm{~g} \mathrm{l}^{-1}$ (Fig. 1B), indicating that osmoregulation capacity was exceeded, and cells were no longer able to uphold turgor, and began to leak and shrink when the salinity became too high. The reduction in cell size in response to osmotic stress is known as plasmolysis, and is also widely reported for other bacteria (Koch 1984, Csonka 1989, Shapiguzov et al. 2005). The combination of leakage and cell lysis most likely resulted in the high extracellular microcystin concentrations observed at salinities exceeding $10 \mathrm{~g} \mathrm{l}^{-1}$ (Fig. 2C). The growth rate and microcystin production rate collapsed when cells were exposed to salinities exceeding $10 \mathrm{~g}$ $1^{-1}$ for several weeks.

The salt-shock experiments show that Microcystis aeruginosa may temporarily withstand even higher salinities. The microcystin cell quota and microcystin production in the salt-shock experiment of $10 \mathrm{~g} \mathrm{l}^{-1}$ match the values found in the experiments with gradually rising salinity. When $M$. aeruginosa was exposed to stronger salt shocks of 15 and $17.5 \mathrm{~g} \mathrm{l}^{-1}$, growth rates and microcystin production declined, but M. aeruginosa was still able to grow and produce microcystins for at least $1 \mathrm{wk}$. During this period the average cell size did not decrease, indicating that the surviving cells were still able to withstand the high turgor pressure. However, extracellular microcystin concentration increased to $30 \%$ of the total microcystin concentration in the cultures exposed to a salinity of $17.5 \mathrm{~g} \mathrm{l}^{-1}$. These findings are consistent with recent salt-shock studies with a mixed Microcystis spp. population from the Swan River estuary in Western Australia, which revealed cell lysis and increased concentrations of extracellular microcystins when cells were exposed to a salinity of $21 \mathrm{~g} \mathrm{l}^{-1}$ (Orr et al. 2004).

What are the environmental implications? In the literature, surprisingly few data are available on the salt tolerance of freshwater phytoplankton species. A compilation of available data is shown in Fig. 3. In line with earlier suggestions (Hart et al. 1991, Nielsen et al. 2003), these data show that many of the freshwater diatoms and green algae thus far investigated have a relatively low salt tolerance. Accordingly, cyanobacteria with a higher salt tolerance, like Microcystis aeruginosa and Anabaena sp., may profit from rising salinities in freshwater ecosystems by gaining a competitive advantage over other freshwater phytoplankton. Conversely, when estuaries face a sudden input of freshwater, $M$. aeruginosa may gain an advantage over resident marine phytoplankton (Robson \& Hamilton 2003). Current management evaluations consider whether several Dutch freshwater areas should be converted into brackish waters (e.g. Lake 


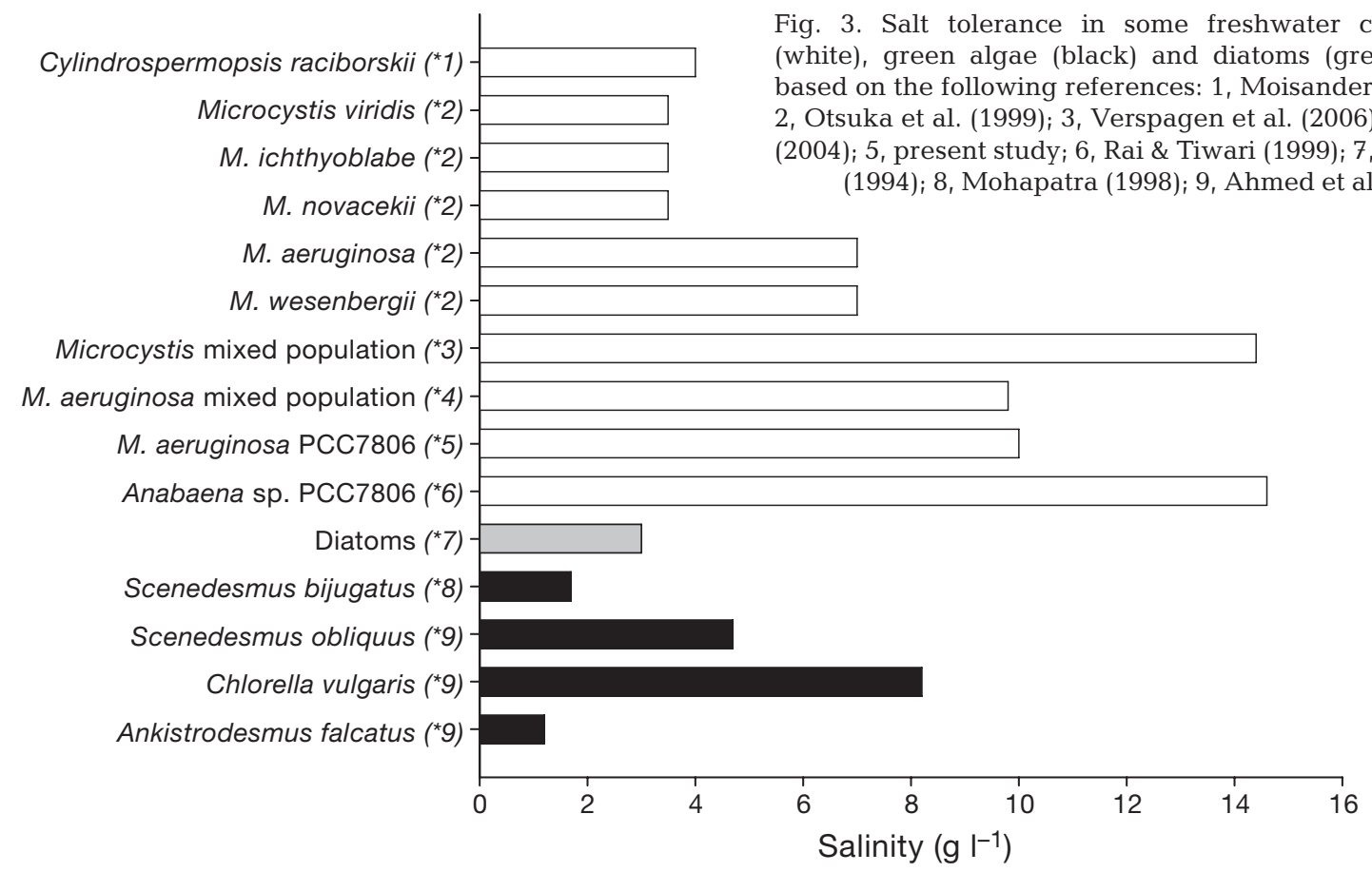

Volkerak; Verspagen et al. 2006). Our results indicate that such large-scale changes in water management might facilitate a competitive advantage of salttolerant cyanobacteria over salt-sensitive freshwater phytoplankton such as green algae and diatoms. Moreover, our results show that temporary exposure to salinities between 10 and $20 \mathrm{~g} \mathrm{l}^{-1}$ allows survival of M. aeruginosa populations, while extracellular microcystin concentrations will increase. This implies that salinity fluctuations in brackish waters may not only favor $M$. aeruginosa over other freshwater phytoplankton species, but may also increase the exposure of many aquatic organisms to elevated microcystin concentrations. In conclusion, a transition of freshwater ecosystems into brackish waters is unlikely to prevent Microcystis spp. blooms, unless salinities increase to sufficiently high levels at which Microcystis spp. no longer survives (i.e. above $17.5 \mathrm{~g} \mathrm{l}^{-1}$ ). Increases in salinity in freshwater ecosystems that remain below this threshold are more likely to enhance the risk of Microcystis spp. blooms and the exposure to elevated concentrations of microcystins.

Acknowledgements. We thank Professor G. A. Codd for kindly providing the MC-LR gravimetrical standard. The research of L.T., P.M.V. and J.H. was supported by the Earth and Life Sciences Foundation (ALW), which is subsidized by the Netherlands Organization for Scientific Research (NWO). L.T. and P.M.V. were additionally supported by a European Union grant within the program PEPCY.

\section{LITERATURE CITED}

Ahmed AM, Mohammed AA, Heikal MD, Mohammed RH (1985) Physiology of some Nile algae. 1. Effect of increased $\mathrm{NaCl}$ concentration in the medium. Acta Hydrobiol 27:25-32

Albay M, Matthiensen A, Codd GA (2005) Occurrence of toxic blue-green algae in the Kucukcekmece Lagoon (Istanbul, Turkey). Environ Toxicol 20:227-284

Bordalo AA, Vieira MEC (2005) Spatial variability of phytoplankton, bacteria and viruses in the mesotidal saltwedge Douro estuary (Portugal). Estuar Coast Shelf Sci 63:143-154

Carmichael WW, Azevedo SMFO, An JS, Molica RJR and 5 others (2001) Human fatalities from cyanobacteria: chemical and biological evidence for cyanotoxins. Environ Health Perspect 109:663-668

Chorus I, Bartram J (1999) Toxic cyanobacteria in water: a guide to their public health consequences, monitoring and management. E \& FN Spon, London

Codd GA, Lindsay J, Young FM, Morrison LF, Metcalf JS (2005) Harmful cyanobacteria: from mass mortalities to management measures. In: Huisman J, Matthijs HCP, Visser PM (eds) Harmful cyanobacteria. Springer, Berlin, p 1-24

Csonka LN (1989) Physiological and genetic responses of bacteria to osmotic stress. Microbiol Rev 53:121-147

DasSarma S, Arora P (2001) Halophiles. In: Encyclopedia of life sciences. Wiley, London; available at http://els.wiley.com

Fastner J, Flieger I, Neumann U (1998) Optimised extraction of microcystins from field samples: a comparison of different solvents and procedures. Water Res 32:3177-3181

Hart BT, Bailey P, Edwards R, Hortle K, James K, McMahon A, Meredith C, Swadling K (1991) A review of the salt sensitivity of the Australian freshwater biota. Hydrobiologia 210:105-144 
Hart BT, Lake PS, Webb JA, Grace MR (2003) Ecological risks to aquatic systems from salinity increases. Aust J Bot 51: 689-702

Huisman J, Matthijs HCP, Visser PM, Balke H, Sigon CAM, Passarge J, Weissing FJ, Mur LR (2002) Principles of the light-limited chemostat: theory and ecological applications. Antonie Leeuwenhoek Int J G 81:117-133

Huisman J, Sharples J, Stroom JM, Visser PM, Kardinaal WEA, Verspagen JMH, Sommeijer B (2004) Changes in turbulent mixing shift competition for light between phytoplankton species. Ecology 85:2960-2970

Huisman J, Matthijs HCP, Visser PM (2005) Harmful cyanobacteria. Springer, Berlin

James KR, Cant B, Ryan T (2003) Responses of freshwater biota to rising salinity levels and implications for saline water management: a review. Aust J Bot 51:703-713

Koch AL (1984) Shrinkage of growing Escherichia coli cells by osmotic stress. J Bacteriol 159:919-924

Lehman PW, Boyer G, Hall C, Waller S, Gehrts K (2005) Distribution and toxicity of a new colonial Microcystis aeruginosa bloom in the San Francisco Bay Estuary, California. Hydrobiologia 541:87-99

Long BM, Jones GJ, Orr PT (2001) Cellular microcystin content in N-limited Microcystis aeruginosa cultures can be predicted from growth rate. Appl Environ Microbiol 67:278-283

MacKintosh C, Beattie KA, Klumpp S, Cohen P, Codd GA (1990) Cyanobacterial microcystin-LR is a potent and specific inhibitor of protein phosphatases 1 and 2A from both mammals and higher plants. FEBS Lett 264:187-192

Matthiensen A, Beattie KA, Yunes JS, Kaya K, Codd GA (2000) [D-Leu(1)]microcystin-LR, from the cyanobacterium Microcystis RST 9501 and from a Microcystis bloom in the Patos Lagoon estuary, Brazil. Phytochemistry 55:383-387

Mohapatra PK, Dash RC, Panda SS, Mishra RK, Mohanty RC (1998) Effects of nutrients at different salinities on growth of the freshwater green alga Scenedesmus bijugatus in water of Narendra Pond, Puri, Orissa. Int Rev Gesamten Hydrobiol 83:297-304

Moisander PH, McClinton E III, Paerl HW (2002) Salinity effects on growth, photosynthetic parameters, and nitrogenase activity in estuarine planktonic cyanobacteria. Microb Ecol 43:432-442

Muylaert K, Sabbe K, Vyverman W (2000) Spatial and temporal dynamics of phytoplankton communities in a freshwater tidal estuary (Schelde, Belgium). Estuar Coast Shelf Sci 50:673-687

Nielsen DL, Brock MA, Rees GN, Baldwin DS (2003) Effects of increasing salinity on freshwater ecosystems in Australia. Aust J Bot 51:655-665

Orr PT, Jones GJ, Douglas GB (2004) Response of cultured Microcystis aeruginosa from the Swan River, Australia, to elevated salt concentration and consequences for bloom

Editorial responsibility: Edna Granéli,

Kalmar, Sweden and toxin management in estuaries. Mar Freshw Res 55: $277-283$

Otsuka S, Suda S, Li R, Watanabe M, Oyaizu H, Matsumoto S, Watanabe MM (1999) Characterization of morphospecies and strains of the genus Microcystis (cyanobacteria) for a reconsideration of species classification. Phycol Res 47: 189-197

Prinsloo DF, Pieterse AJH (1994) Preliminary observations on the effect of increased concentrations of total dissolved salts on growth and photosynthetic rates in different algal species. Water SA (Pretoria) 20:219-222

Rai AK, Tiwari SP (1999) $\mathrm{NO}_{3}{ }^{-}$nutrition and salt tolerance in the cyanobacterium Anabaena sp. PCC 7120 and mutant strains. J Appl Microbiol 86:991-998

Reynolds CS, Walsby AE (1975) Water blooms. Biol Rev 50:437-481

Robson BJ, Hamilton DP (2003) Summer flow event induces a cyanobacterial bloom in a seasonal Western Australian estuary. Mar Freshw Res 54:139-151

Sabour B, Loudiki M, Oudra B, Oubraim S, Fawzi B, Fadlaoui S, Chlaida M, Vasconcelos V (2002) First results on Microcystis ichthyoblabe Kutz. toxic bloom in the hypertrophic Oued Mellah reservoir (Morocco). Ann Limnol 38:13-22

Shapiguzov A, Lyukevich AA, Allakhverdiev SI, Sergeyenko TV, Suzuki I, Murata N, Los DA (2005) Osmotic shrinkage of cells of Synechocystis spp. PCC 6803 by water efflux via aquaporins regulates osmostress-inducible gene expression. Microbiology (Reading) 151:447-455

Tonk L, Visser PM, Christiansen G, Dittmann E, Snelder EOFM, Wiedner C, Mur LR, Huisman J (2005) The microcystin composition of the cyanobacterium Planktothrix agardhii changes towards a more toxic variant with increasing light intensity. Appl Environ Microbiol 71:5177-5181

van Liere L, Mur LR (1978) Light limited cultures of the blue green alga Oscillatoria agardhii. Mitt Int Ver Theor Angew Limnol 21:158-167

Verspagen JMH, Passarge J, Jöhnk KD, Visser PM, Peperzak L, Boers P, Laanbroek HJ, Huisman J (2006) Water management strategies against toxic Microcystis blooms in the Dutch delta. Ecol Appl 16:313-327

Visser PM, Ibelings BW, Mur LR, Walsby AE (2005) The ecophysiology of the harmful cyanobacterium Microcystis: features explaining its success and measures for its control. In: Huisman J, Matthijs HCP, Visser PM (eds) Harmful cyanobacteria. Springer, Berlin, p 109-142

Williams WD (2001) Anthropogenic salinisation of inland waters. Hydrobiologia 466:329-337

Wilson SE, Cumming BF, Smol JP (1994) Diatom-salinity relationships in 111 lakes from the Interior Plateau of British Columbia, Canada: the development of diatombased models for paleosalinity reconstructions. J Paleolimnol 12:197-221

Submitted: June 21, 2006; Accepted: October 4, 2006

Proofs received from author(s): January 10, 2007 